\title{
Using Delone \& McLean Information System Success Model to Evaluate the Success of Online Platform
}

\author{
Yohanes Farley Viriando, Sfenrianto \\ Information Systems Management Department, Bina Nusantara University, Jakarta \\ 11480, Indonesia \\ yohanes.viriando@binus.ac.id,sfenrianto@binus.edu
}

\begin{abstract}
The platform that functions as a place for buying and selling online voucher reservations for tours owned by PT XYZ is used by tourists and product and service owners to transact with each other with the efficiency and effectiveness offered by the platform. There is a problem with this platform which causes the platform owner to get several complaints from its users about users, namely tourists who have purchased the tour voucher, but when the location has run out of places or products and services that have been purchased due to collisions with users from competitors whose orders will not be integrated to the PT XYZ's system or there are non-technical problems at these tourist sites that require tourists not to be able to use the vouchers, and as far as the platform is implemented, there has never been a measurement of what factors affect the successful implementation of the platform to see the success of its implementation. This study uses variables from the success of Delone and McLean's Information Systems, namely information quality, system quality, service quality, usage, user satisfaction, net benefits, and added with external variables, namely trust based on the modified research of Delone and McLean's model. This study was tested with a structural equation model - partial least square with SmartPLS 3 software. Online questionnaires were distributed to a total sample of 262 respondents via Google Form. This study concludes that 9 out of 10 hypotheses are considered proven and system quality, information quality, and service quality are three constructs that are proven to directly affect net use and benefits, and use is strongly influenced by information quality, service quality, and trust.
\end{abstract}

Keywords: Delone and McLean Information System Success Model, platform, trust, SEM-PLS. 


\section{Introduction}

The times in the increasingly modern era of globalization require humans to continue to create innovations with the help of technology that can support various human activities in all aspects of social life. Technology makes it easier for humans to carry out all their activities. Demands from the times that continue to develop into businessmen to continue to compete by creating new things, the field of information technology.

Information technology helps humans in carrying out business processes to process their data into information that can be a positive benefit because it will be the facility for the activity, and this will certainly have a good impact on the company. The development of increasingly sophisticated information technology from time to time has made companies continue to innovate to digitize their business processes that were previously done manually or without the help of technology. The use of information technology is carried out by building and applying information technology that has been developed into a business so that the business becomes effective and is called an information system (Pranoto, 2016). Information systems have been used by various industrial fields, one of which is the tourism sector.

The tourism industry in Indonesia according to Bank Indonesia is the most effective foreign exchange booster sector because domestically there are human resources, a large area, and the diversity needed to develop tourism (Gewati, 2019). This is evidenced by the contribution of foreign exchange from the tourism sector which has continued to increase significantly over the last five years, which means that both foreign and domestic tourists also continue to increase.

The tourism industry has a lot of services and products that are offered to both foreign and domestic tourists. Broadly speaking, the services and services offered by tourism are accommodation, food and beverage activities, transportation, travel agents, and various entertainment and recreational activities. Services and products from tourism by utilizing technology will increase the number of tourists and speed up and speed up the business processes contained therein. The use of technology in the tourism industry can affect the company's success.

However, the use of this technology does not necessarily guarantee the system that has been created. The possibility that the system has been designed and implemented does not always have a positive impact. In this case, PT XYZ has implemented a system called the online reservation buying and selling platform for tours that are used by tourists to buy vouchers purchased by top-up points with payment through the payment gateways that have been provided, and then these vouchers can be used for tourism in the category accommodation, transportation, restaurants, activities, and attractions provided by the merchants

In the business process, users of the platform, namely tourists, will choose the desired voucher according to the category, then the details of the voucher and the 
data form that must be filled will appear. Once filled, the user will click the book now button after which the payment details will appear which will reduce the points from the user if the points are sufficient to buy the voucher. After purchasing, the voucher and transaction data will be sent via email which can then be redeemed at the destination that has been visited.

The platform that has been implemented will certainly make it easier for tourists to obtain information and do not need to queue or pay illegal fees that should not be a tourist fee. However, in reality, according to PT XYZ, there are problems for tourists who have purchased the tour vouchers but when they arrive at the location, the places or products and services that have been purchased have run out due to collisions with users from competitors whose orders will not be integrated into the PT XYZ system or there are problems non-technical at these tourist locations which require tourists not to be able to use the voucher, resulting in users having to take care of a refund, the process takes time and find solutions to the problem of unavailability of the destination or products and services that have been selected and purchased And as far as the platform has been implemented, PT XYZ has never taken measurements before.

Based on these problems and reasons, measuring the success of the platform must be done. From various measurement models such as UTAUT which are used only to evaluate user acceptance of systems related to academics and TAM which explains user behavior when offered to use a new system, several factors influence their decisions about how and when to use the system (Hamrul et al., 2013), Modified Updated Delone \& McLean IS Success Model was chosen to see the net benefits added by external factors, namely trust to see the extent of user trust in the platform because users must provide personal data and transaction data to maximize the features available on PT's platform. XYZ. Modified Updated Delone \& McLean IS Success Model is used because this model is suitable for measuring the success of a system and has been proven to be used in various measures of system success so that the measurement to be carried out can be a study to evaluate the problem that is happening, and with Doing the research, it is hoped that PT XYZ as a platform provider can find out the situation and make improvements or improvements to the system.

\section{Theoretical Background}

Digital platforms can be used to regulate various human activities such as social, political, and economic interactions. In the economic field, a platform used by the tourism industry will continue to develop and grow in the future, to develop business and adapt and compete with business competitors. The platform used by the tourist is a website-based platform that is used to support business processes between the tourist and merchants.

A. Travel 
In theory, travel or tourism in Indonesia comes from Sanskrit which means travel, which is currently developing with a "recreational" motivation, namely for a vacation (Kodyat, 2013). Scientifically, travel or tourism is a trip and stopover made by humans outside their place of residence with various motivations but not to change places of residence and settle in the places visited or stopover, or to do jobs for a fee. Travel actors are usually referred to as travelers or tourists.

A traveler is a temporary visitor who stays at least 24 hours at his destination. Destinations are classified as leisure or excursions, namely leisure needs, and noncruise, namely business needs. The difference between excursions and non-cruises is leisure or excursions, namely for vacation, health, study, religion or pilgrimage, and sports, while non-excursions are trade or business relations, family visits, conferences, and missions.

Initially, travel or tourism activities were carried out for visiting a holy place or for business purposes. It is undeniable that traveling activities are consumptive, as long as the activities are carried out, travelers spend money to meet consumptive needs such as staying at hotels, eating and drinking at restaurants, local transportation costs, and also for entertainment.

B. Online Travel Agent

The internet has a growing influence in various tourism markets, this is because consumer information and their ordering behavior have changed dramatically since online services and orders were introduced (Lohmann and Schmücker, 2009).

The growth of the tourism industry requires information technology to manage the increasing volume and quality of tourism (Law et al., 2004). In recent years, the emergence of the online marketplace has dramatically changed the travel industry, making it one of the most advanced online businesses (Shapiro and Shi, 2008). With the advent of information and communication technology in this century, tourism has also started to be pushed into online channels, suppliers and intermediaries are now struggling in fierce competition to sell their services through e-commerce (Vilarinho, 2014).

C. Digital Platform

Digital platforms can be used to regulate various human activities such as in social, political, and economic interactions (Tan Barney et al., 2015). In the economic field, the platform is used by the banking industry, which will continue to develop and grow in the future, to develop business and adapt and compete with business competitors (Omarini, 2018).

D. Delone and Mclean Information System Success Model

Delone \& McLean's IS Success Model is a framework for measuring complex independent variables in information systems research (DeLone and McLean, 2003). Delone \& McLean IS Success Model is a comprehensive model which is supported by many studies and reviews 180 studies from seven Management Information System publications and synthesizes six factors that contribute to the success of an 
information system.

This proposed model reflects the dependence on measuring the success of information systems. The six elements or measurement components of this model are system quality, information quality, use, user satisfaction, individual impact, and organizational impact.

Measurement of the success of information systems has also evolved. Therefore, Delone and McLean reviewed, re-tested, and reformulated the D\&M IS Success Model. In 2003, Delone and McLean then revised the model to become Delone and McLean's Information Success Update Model. In this revised model, Delone and McLean add a service quality dimension and combine two dimensions: individual influence and organizational influence into a net benefit dimension (DeLone and McLean, 2003). The difference in the model lies in the additional dimensions in The Updated Delone \& McLean IS Success Model, namely service quality and net benefits. In the Updated Delone \& McLean IS Success Model, Delone and McLean recommend adding service quality as an equally important dimension to the success of information systems, apart from systems quality and information quality.

The following is an explanation of the six dimensions of the success of Delone \& McLean's information system success model (Mudzana and Maharaj, 2015):

1. System Quality

System quality in the Delone \& McLean model can be explained as a dimension of expected information characteristics in terms of usability and performance characteristics of a system. System quality affects Use and User Satisfaction (Iivari, 2005).

According to (Gable, 2008; Iivari, 2005; Seddon, 1997) indicators used to explain system quality are easy to use, access information, and real-time access.

2. Information Quality

Information quality can be explained as a dimension of expected information system characteristics in terms of output. The output in question is related to the value, benefits, relevance, and urgency of the information generated. Information quality affects Use and User Satisfaction (Iivari, 2005).

According to (Bharati and Chaudhury, 2004; Liu and Arnett, 2000; Iivari, 2005), there are three indicators of information quality, namely accurate information, information as needed, and current information.

3. Service Quality

Service quality in the Delone \& McLean model can be explained as a representation of the quality of support received by system users. Service quality affects Use and User Satisfaction (Scott et al., 2011).

According to (Petter et al., 2015; Safdari et al., 2014; Rai et al.,2002)indicators used to explain the service quality of the system in this study consist of from safe to access, can provide input, reliable manager.

4. Use 
The use in the Delone \& McLean model can be explained as a focus on the benefits that will be received by the user. The benefit, in this case, is how the system can be utilized and used by users. Use affects User Satisfaction (Bokhari, 2005).

The indicators used to explain the use of the system in this study according to (Petter et al., 2015; Rai et al.,2002) consist of being influenced by customers, accustomed to using, the intention to keep using.

\section{User Satisfaction}

In the Delone \& McLean model, user satisfaction is the level or level of satisfaction when utilizing information systems. This dimension is one of the most important information system success factors. Customer satisfaction affects Use (Baroudi et al, 1986).

The indicators used to explain customer satisfaction using the system in this study according to (Petter et al., 2015; Rai et al.,2002) consist of being influenced by customers, accustomed to using, and the intention to keep using.

\section{Net Benefit}

Net Benefit in the Delone \& McLean model is the point where an information system contributes to the success of stakeholders. Net benefits are influenced by use and user satisfaction (Delone Mclean, 2015).

According to (Petter et al., 2015; Wu and Wang, 2006), the indicators used to explain Net Benefit in this study consist of speeding up work, better selfperformance, useful in completing work.

\section{Trust}

Trust is an external factor that is not included in the Delone \& McLean model, which is a key factor that determines the perceived quality of the user, which in turn has an impact on the satisfaction and intention of continuous use of the user (Teo et al., 2008).

According to (Stewart, 2003; Lee and Chung, 2009) indicators used to explain trust in this study consist of trusting in security, services according to needs, not having to provide data.

Based on the related works that have been conducted using the Delone \& McLean Information System Success Model, it has found findings such as most of the research in several industries on the quality variables of the information system quality of information, system quality, service quality has a significant effect on user satisfaction and usage, while trust also affects user usage and satisfaction, these six factors are the most important in a platform and are added by the net benefits obtained by user usage and satisfaction.

Several factors such as social networking services, quality of interface design, intention to reuse, privacy factors are also used as external factors in the Delone $\&$ McLean Information System Success Model, but social networking and interface design quality do not affect the variables contained in the Delone \& McLean 
Information Systems Success Model.

\section{Research Design}

The research was conducted using a quantitative method to gather the data by distributing an online questionnaire with a Likert scale to the respondents of this research. Likert scale divided on a scale of one to five that ranges from very negative to very positive, one representing strongly disagree and five representing strongly agree (Sekaran and Bougie, 2016). The respondents are users of the platform that is a tourist. The population of this study is 757 peoples and sample were used due to limited costs, energy, and time this research to represent the population, by using Slovin's formula, the calculation with an error that used in sampling is $5 \%$ of the sample resulted in 262 peoples.

\section{A. Research Model}

The research model used is the Modified Updated Delone \& McLean IS Success Model referring to Figure 1. This model is suitable for measuring the success rate of the system by looking at the net benefit of the platform that has been used by the tourist.

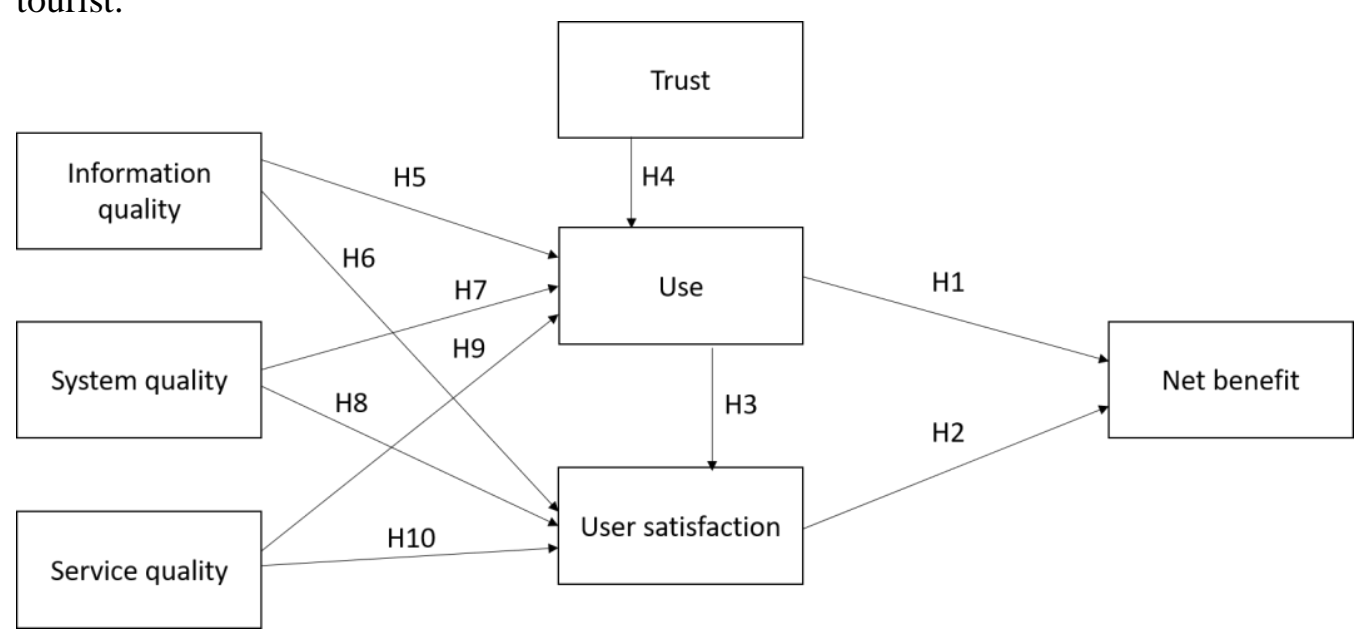

Fig. 1: Research Model and Hypothesis

There are six main variables in the Updated Delone \& McLean IS Success Model, namely system quality, information quality, service quality, use, user satisfaction, and net benefits. Some factors come from outside or external, namely trust.

Measuring variables require the right indicators to be done right. The indicator description used in this research is stated below

Table 1: Indicator Description

\begin{tabular}{|l|l|l|l|}
\hline Variable & Description & Indicator & Source \\
\hline Information & $\begin{array}{l}\text { The quality of the } \\
\text { information provided is }\end{array}$ & $\begin{array}{l}\text { Accurate information (IQ1) } \\
\text { Information as needed (IQ2) }\end{array}$ & $\begin{array}{l}\text { Pranoto, } \\
\text { 2016; Gewati, }\end{array}$ \\
\hline
\end{tabular}




\begin{tabular}{|c|c|c|c|}
\hline Quality & $\begin{array}{l}\text { accurate, complete, relevant, } \\
\text { and current. }\end{array}$ & Current information (IQ3). & $\begin{array}{l}\text { 2019; Hamrul } \\
\text { et al., 2013) }\end{array}$ \\
\hline $\begin{array}{l}\text { System } \\
\text { Quality }\end{array}$ & $\begin{array}{l}\text { The quality of the system is } \\
\text { good by providing } \\
\text { convenience and comfort in } \\
\text { using it }\end{array}$ & $\begin{array}{l}\text { Easy to use (SQ1) } \\
\text { Accessing information } \\
\text { (SQ2) } \\
\text { Real-time access (SQ3). }\end{array}$ & $\begin{array}{l}\text { (Kodyat, } \\
\text { 2013; Hamrul } \\
\text { et al., 2013; } \\
\text { Lohmann and } \\
\text { Schmücker, } \\
\text { 2009) }\end{array}$ \\
\hline $\begin{array}{l}\text { Service } \\
\text { Quality }\end{array}$ & $\begin{array}{l}\text { Quality of service or support } \\
\text { received by system users by } \\
\text { providing accuracy, } \\
\text { reliability, technical } \\
\text { competence in services. }\end{array}$ & $\begin{array}{l}\text { Safe access (SEQ1) } \\
\text { Can give input (SEQ2) } \\
\text { Reliable manager (SEQ3). }\end{array}$ & $\begin{array}{l}\text { (Law et al., } \\
\text { 2004; } \\
\text { Shapiro and } \\
\text { Shi; } \\
\text { Vilarinho, } \\
\text { 2014) }\end{array}$ \\
\hline Use & $\begin{array}{l}\text { User behavior or actions in } \\
\text { using the system }\end{array}$ & $\begin{array}{l}\text { Customer affected (U1) } \\
\text { Accustomed to using (U2) } \\
\text { The intention remains to use } \\
\text { (U3). }\end{array}$ & $\begin{array}{l}\text { (Law et al., } \\
\text { 2004; } \\
\text { Vilarinho, } \\
\text { 2014) }\end{array}$ \\
\hline $\begin{array}{l}\text { User } \\
\text { Satisfaction }\end{array}$ & $\begin{array}{l}\text { The level of user satisfaction } \\
\text { with the system. The single } \\
\text { item for measuring user } \\
\text { satisfaction, the semantic } \\
\text { differential scale for } \\
\text { assessing attitudes and } \\
\text { satisfaction with the system, } \\
\text { multi-attribute scale for } \\
\text { measuring user information } \\
\text { satisfaction. }\end{array}$ & $\begin{array}{l}\text { Satisfied and will use again } \\
\text { (US1) } \\
\text { As required (US2) } \\
\text { Service by job (US3) }\end{array}$ & $\begin{array}{l}\text { (Tan Barney } \\
\text { et al., 2015; } \\
\text { Vilarinho, } \\
\text { 2014; } \\
\text { Omarini, } \\
\text { 2018) }\end{array}$ \\
\hline Net Benefit & $\begin{array}{l}\text { The system contributes to } \\
\text { the success of an individual, } \\
\text { group, organization, } \\
\text { industry, the country through } \\
\text { efficiency, the quality } \\
\text { provided, performance, and } \\
\text { knowledge. } \\
\end{array}$ & $\begin{array}{l}\text { Speed up work (NB1) } \\
\text { Better self-performance } \\
\text { (NB2) } \\
\text { Useful in completing work } \\
\text { (NB3) }\end{array}$ & $\begin{array}{l}\text { (Law et al., } \\
\text { 2004; } \\
\text { DeLone and } \\
\text { McLean, } \\
\text { 2003) }\end{array}$ \\
\hline Trust & $\begin{array}{l}\text { A key factor that determines } \\
\text { the perceived quality of the } \\
\text { user, which in turn has an } \\
\text { impact on the satisfaction } \\
\text { and intentions of continuous } \\
\text { use of the user. }\end{array}$ & $\begin{array}{l}\text { Trust in security (T1) } \\
\text { Services as needed (T2) } \\
\text { No need to provide data (T3) }\end{array}$ & $\begin{array}{l}\text { (Mudzana } \\
\text { and Maharaj, } \\
\text { 2015; Iivari, } \\
\text { 2005; Gable, } \\
\text { 2008) }\end{array}$ \\
\hline
\end{tabular}

\section{B. Hypothesis}

Based on the descriptions and literature studies that have been carried out, the following hypotheses are produced.

The regression equation is used to analyze the data that will be processed in the next section. The equations are:

$\mathrm{NB}=\beta 10+\beta 11 \mathrm{U}+\beta 12 \mathrm{US}+\mathrm{C} 1$ 


$$
\begin{aligned}
& \mathrm{US}=\beta 20+\beta 21 \mathrm{U}+\beta 22 \mathrm{IQ}+\beta 23 \mathrm{SQ}+\beta 24 \mathrm{SEQ}+\mathrm{C} 2 \ldots \text { (2) } \\
& \mathrm{U}=\beta 30+\beta 31 \mathrm{IQ}+\beta 32 \mathrm{SQ}+\beta 33 \mathrm{SEQ}+\beta 34 \mathrm{~T}+\mathrm{C} 3 \ldots \text { (3) }
\end{aligned}
$$

Table 2: Hypothesis

\begin{tabular}{|l|l|lll|}
\hline No. & \multicolumn{1}{|c|}{ Hypothesis } & \multicolumn{4}{|c|}{ Description } \\
\hline 1 & Hypothesis 1 & Use has a significant influence on Net Benefit. & \\
\hline 2 & Hypothesis 2 & User Satisfaction has a significant influence on Net Benefit \\
\hline 3 & Hypothesis 3 & Use has a significant influence on User Satisfaction. & \\
\hline 4 & Hypothesis 4 & Trust has a significant influence on Use. \\
\hline 5 & Hypothesis 5 & Information Quality has a significant effect on Use. & \\
\hline 6 & Hypothesis 6 & $\begin{array}{l}\text { Information Quality has a significant influence on User } \\
\text { Satisfaction. }\end{array}$ \\
\hline 7 & Hypothesis 7 & System Quality has a significant influence on Use. & \\
\hline 8 & Hypothesis 8 & $\begin{array}{l}\text { System Quality has a significant influence on User } \\
\text { Satisfaction. }\end{array}$ \\
\hline 9 & Hypothesis 9 & Service Quality has a significant influence on Use. & \\
\hline 10 & Hypothesis 10 & $\begin{array}{l}\text { Service Quality has a significant influence on User } \\
\text { Satisfaction. }\end{array}$ \\
\hline
\end{tabular}

By using regression equation, it will be proven whether NB or US or $U=0$ or not. If the result of $\beta \mathrm{i}$ is 0 , it means that $\mathrm{NB}$ or US or $\mathrm{U}$ is not affected by its $\mathrm{Xi}$, and to measure the relationship between variables P-value will be observed. Statistics of the hypothesis stated as follows:

1. H0: $\beta 11=0$ There is no effect between Use and Net Benefit

Ha: $\beta 11 \neq 0$ Use affects Net Benefits significantly

2. H0: $\beta 12=0$ There is no influence between User Satisfaction and Net Benefits

Ha: $\beta 12 \neq 0$ User Satisfaction significantly affects Net Benefits

3. H0: $\beta 21=0$ There is no influence between Usage and User Satisfaction

Ha: $\beta 21 \neq 0$ Use affects User Satisfaction significantly

4. 4. H0: $\beta 22=0$ There is no influence between Information Quality and User Satisfaction

Ha: $\beta 22 \neq 0$ Information quality significantly affects User Satisfaction

5. H0: $\beta 23=0$ There is no influence between System Quality and User Satisfaction

Ha: $\beta 23 \neq 0$ System quality significantly affects User Satisfaction

6. H0: $\beta 24=0$ There is no influence between Service Quality and User Satisfaction

Ha: $\beta 24 \neq 0$ Service quality significantly affects User Satisfaction

7. H0: $\beta 31=0$ There is no influence between the quality of information and usage

Ha: $\beta 31 \neq 0$ Information quality affects usage significantly

8. H0: $\beta 32=0$ There is no influence between System Quality and Usage

Ha: $\beta 32 \neq 0$ System quality affects usage significantly 
9. H0: $\beta 33=0$ There is no influence between Service Quality and Usage

Ha: $\beta 33 \neq 0$ Service quality affects usage significantly

10. H0: $\beta 34=0$ There is no influence between Trust and Use

Ha: $\beta 34 \neq 0$ Trust affects usage significantly

\section{Result and Discussion}

After data were collected from an online questionnaire, the validity and reliability of the data were tested before the hypothesis test to ensure the data are valid and reliable. Data collection from respondents who filled the questionnaire in this research is 262 respondents. Below are the result table of validity and reliability tests with Average Variance Extracted (AVE) value more than equal to 0,5 and loading factor more than equal to 0,5 with the ideal more than equal to 0,7 (Hair et al., 2006). Below is the result table of the validity test.

Table 3: Validity Result

\begin{tabular}{|c|c|c|c|c|}
\hline Variable & Indicator & Loading Factor & AVE & Result \\
\hline \multirow[t]{3}{*}{ System Quality } & SQ1 & 0,819 & \multirow{3}{*}{0,573} & Valid \\
\hline & SQ2 & 0,743 & & Valid \\
\hline & SQ3 & 0,705 & & Valid \\
\hline \multirow[t]{3}{*}{ Information Quality } & IQ1 & 0,749 & \multirow{3}{*}{0,559} & Valid \\
\hline & IQ2 & 0,667 & & Valid \\
\hline & IQ3 & 0,819 & & Valid \\
\hline \multirow[t]{3}{*}{ Service Quality } & SEQ1 & 0,760 & \multirow{3}{*}{0,650} & Valid \\
\hline & SEQ2 & 0,784 & & Valid \\
\hline & SEQ3 & 0,871 & & Valid \\
\hline \multirow[t]{3}{*}{ Use } & U1 & 0,771 & \multirow{3}{*}{0,671} & Valid \\
\hline & U2 & 0,871 & & Valid \\
\hline & U3 & 0,812 & & Valid \\
\hline \multirow[t]{3}{*}{ User Satisfaction } & US1 & 0,863 & \multirow{3}{*}{0,647} & Valid \\
\hline & US2 & 0,896 & & Valid \\
\hline & US3 & 0,629 & & Valid \\
\hline \multirow[t]{3}{*}{ Net Benefit } & NB1 & 0,810 & \multirow{3}{*}{0,621} & Valid \\
\hline & NB2 & 0,785 & & Valid \\
\hline & NB3 & 0,769 & & Valid \\
\hline \multirow[t]{3}{*}{ Trust } & $\mathrm{T} 1$ & 0,780 & \multirow{3}{*}{0,614} & Valid \\
\hline & $\mathrm{T} 2$ & 0,771 & & Valid \\
\hline & T3 & 0,798 & & Valid \\
\hline
\end{tabular}

Based on the table above, the variables are having more than 0,5 loading factor and 0,5 AVE. Hence, the indicator in this research can be declared as data that valid and fit for use. After done validity and reliability, consistency in each statement in the questionnaire needs to be measure. Cronbach's Alpha and Composite Reliability value will determine the consistency, a value between 0,6 and 0,7 or more indicates the indicator has a good value (Hair et al., 2006). Below is the result table of the reliability test. 
Table 4: Reliability Result

\begin{tabular}{|l|l|l|}
\hline & Cronbach's Alpha & Composite Reliability \\
\hline System Quality & 0,629 & 0,801 \\
\hline Information Quality & 0,608 & 0,791 \\
\hline Service Quality & 0,732 & 0,848 \\
\hline Use & 0,757 & 0,859 \\
\hline User Satisfaction & 0,721 & 0,843 \\
\hline Net Benefit & 0,695 & 0,831 \\
\hline Trust & 0,686 & 0,826 \\
\hline
\end{tabular}

The table above shown Cronbach's Alpha value of each variable is more than 0,6 and the Composite Reliability value is more than 0,7 (Hair et al., 2006). Both values concluded variables used in this research can be stated as reliable.

Subsequently, the hypothesis can be analyzed. The acceptable value for the hypothesis is a value that more than equal to 0,05 . P-values are used to find out if the relationships between variables will be accepted or rejected as shown in the table below.

Table 5: Hypothesis Result

\begin{tabular}{|l|l|l|}
\hline & P-Value & Result \\
\hline Use $\rightarrow$ Net Benefit & 0,001 & Significant \\
\hline User Satisfaction $\rightarrow$ Net Benefit & 0,000 & Significant \\
\hline Use $\rightarrow$ User Satisfaction & 0,000 & Significant \\
\hline Trust $\rightarrow$ Use & 0,000 & Significant \\
\hline Information Quality $\rightarrow$ Use & 0,000 & Significant \\
\hline Information Quality $\rightarrow$ User Satisfaction & 0,048 & Significant \\
\hline System Quality $\rightarrow$ Use & 0,662 & Not Significant \\
\hline System Quality $\rightarrow$ User Satisfaction & 0,000 & Significant \\
\hline Service Quality $\rightarrow$ Use & 0,035 & Significant \\
\hline Service Quality $\rightarrow$ User Satisfaction & 0,000 & Significant \\
\hline
\end{tabular}

Result of data processing shown that the very significant hypotheses are, H1 (Use $\rightarrow$ Net Benefit), H2 (User Satisfaction $\rightarrow$ Net Benefit), H3 (Use $\rightarrow$ User Satisfaction), H4 (Trust $\rightarrow$ Use), H5 (Information Quality $\rightarrow$ Use), H8 (System Quality $\rightarrow$ User Satisfaction), and H10 (Service Quality $\rightarrow$ User Satisfaction).

Significant hypotheses are, H6 (Information Quality $\rightarrow$ User Satisfaction) and H9 (Service Quality $\rightarrow$ Use).

While there is one not significant hypothesis which is H7 (System Quality $\rightarrow$ Use) with 0,662 p-values, that means there is no influence between System Quality and Use.

\section{Conclusion}

After the hypotheses are tested and the results are stated, the conclusion from the results and implications can be detailed from the very significant hypotheses as 
follows.

In this study, the Delone \& Mclean Information System Success Model was used with references to previous studies that were related to assisting research in identifying what factors influence the success of PT XYZ's platform. Analysis of the measurement model shows that all variables have met the validity and reliability criteria as well as the structural model analysis. Based on the results of the study, 9 out of 10 hypotheses were proposed, namely hypothesis 1 , hypothesis 2 , hypothesis 3 , hypothesis 4 , hypothesis 6 , hypothesis 7 , hypothesis 8 , hypothesis 9 , hypothesis 10, which were accepted and concluded several things such as:

1. The results of hypothesis testing show that system quality, information quality, and service quality are the three constructs that have been shown to directly affect use and net benefits.

2. The use of PT XYZ's platform is influenced by several factors which depend on the conditions and environment in which the platform is used. The results of data processing show that 3 of the 10 proposed hypotheses, namely use are strongly influenced by information quality, service quality, and trust.

\section{Use affects Net Benefit}

Based on the research results, use on PT XYZ's platform affects net benefits, which means that system developers must maintain and improve the benefits that already exist in their use so that in the future they can have more benefits that can be felt by users.

\section{User Satisfaction affects Net Benefit}

From the results of hypothesis testing that has been done, the user satisfaction factor has a significant effect on the net benefits of PT XYZ's platform. Perceived satisfaction of platform users also has a beneficial impact on users because of the system quality, information quality, service quality that the PT XYZ platform has.

\section{Use affects User Satisfaction}

Based on the research results, the use of PT XYZ's platform affects the satisfaction of its users due to the efficiency and effectiveness of time and costs in transactions offered by PT XYZ's platform. This certainly changes the experience of its users in purchasing products and services related to travel, the ease of use makes the process on the platform satisfying to its users.

\section{Information Quality affects User Satisfaction}

The quality of information contained in the PT XYZ platform is a factor that affects the satisfaction of its users. Apart from its use, the quality of information also makes users feel satisfied, the accuracy of the information, the relevance of the information to the needs of the users and the latest information available on PT XYZ's platform makes its users feel satisfied. This quality needs to be maintained by the developers of PT XYZ's platform, maybe it can be improved by adding information about frequently asked questions from most users.

7. System Quality affects User Satisfaction 
Apart from information quality factors, system quality also has an influence on user satisfaction. The quality of the platform is considered easy to use, can access information, and real time access makes users satisfied. The quality of the good system will make users feel satisfied and will continue to use PT XYZ's platform again.

8. Service Quality affects User Satisfaction

After the previous three factors affect the satisfaction of users, service quality is also a factor that affects user satisfaction. Security in accessing the platform, being able to provide input, and a reliable manager makes users feel safe and can contribute suggestions and criticism to PT XYZ which then if there are problems or obstacles, the manager of the PT XYZ platform will help in solving the problems experienced by its users.

9. Information Quality affects Use

The factor that has an influence on the use of PT XYZ's platform is the quality of information, in addition to affecting user satisfaction, this factor also affects the use of PT XYZ's platform. With quality information, the use of the platform will also be maintained or even increase transactions.

10. Service Quality affects Use

Apart from information quality, service quality is also a factor that influences usage. Good service quality will keep users on and using PT XYZ's platform. By maintaining the quality of service, users will continue to use PT XYZ's platform due to the quality of service felt by users.

11. Trust affects Use

Use that is influenced by the quality of information and quality of service is also influenced by the trust of its users. With users who trust PT XYZ to provide and receive information on the platform, it will support the use of the platform so that transactions can be carried out as well as problem solving or for increased use of the platform in the future.

The rejected hypothesis can be concluded as follows.

1. There is no influence between System Quality and Use means the quality of the information provided by the platform does not influence User Satisfaction.

The platform owned by PT XYZ has many factors which have been proven in this study to have a significant influence that affects users both in experiencing the net benefits, usage, and user satisfaction of the platform. The quality of information, quality of service, and trust of PT XYZ's platform influence the use of PT XYZ's platform, by paying attention to, maintain and improve these three things, PT XYZ can keep its users using PT XYZ's platform so that it can compete with its competitors. Also, user satisfaction which is influenced by usage, system quality, information quality, and service quality must be maintained and improved by PT $\mathrm{XYZ}$, so that users of the platform will remain satisfied and not disappointed or disadvantaged in making transactions through the PT XYZ platform. With the use 
and satisfaction of users, the net benefits will be felt by users so that this platform is not only satisfying and useful but also has a good impact on users.

With the research that has been done, suggestions or recommendations that can be given to PT XYZ regarding the development of the platform are to pay attention to several aspects, namely:

1. Increase the net benefits of the platform by maximizing user usage and satisfaction by improving and enhancing the quality of the system, information quality, service quality, and the trustworthiness of PT XYZ's platform.

2. In user satisfaction, PT XYZ can improve quality by preparing customer service with response time to user problems quickly so as to solve problems that make it easier for users to get solutions to these problems in the least possible time and get support in solving problems. Good response and time to solve problems will make users feel satisfied. Improving the quality of information can also be done by providing accurate information and always updating any information on the platform. The quality of the system can also be improved by providing convenience and comfort in using the platform so that users will reuse it because PT XYZ's platform matches the needs of its users.

3. In use, PT XYZ can improve the quality of information by presenting a chat bot feature so that users can easily ask for information regarding the products and services they want to buy. The quality of service can be improved by providing customer service access on the platform through the live chat feature with customer service so that users can solve problems more quickly and support them to solve these problems.

4. For government regulators such as the Ministry of Tourism and Creative Economy of the Republic of Indonesia, can support the activities of tourism actors by providing support and assistance to PT XYZ to develop this platform because of its excellent potential for use by a wider range of tourists. The general public supports by continuing to use PT XYZ's platform and providing input that can help PT XYZ in the development or improvement of the platform. For the tourism industry, travel applications or platforms can make this research an illustration of the ideal platform in this field. As for the next researcher, it can be used as learning material or the basis for research that will be carried out in the future.

\section{References}

Baroudi J. J., Olson M. H., and Ives B. (1986). An Empirical Study of the Impact of User Involvement on System Usage and Information Satisfaction, Commun. ACM, 29(3), 232-238.

Bharati P. and Chaudhury A. (2004). An empirical investigation of decision-making satisfaction in web-based decision support systems, Decis. Support Syst., 37(2), 187-197. 
Bokhari R. H. (2005). The relationship between system usage and user satisfaction: A meta-analysis. J. Enterp. Inf. Manag, 18(2), 211-234, 2005

DeLone W. H. and McLean E. R. (2003). The DeLone and McLean model of information systems success: A ten-year update. J. Manag. Inf. Syst., 19(4), 9-30.

Delone W. H. and Mclean E. R. (2015). Applying the DeLone \& McLean Information Systems Success Model Measuring e-Commerce Success: Applying the DeLone \& McLean Information Systems Success Model. International Journal of Electronic Commerce Measuring e-Commerce Success. 37-41.

Gable G. G. (2008), Re-conceptualizing Information System Success: The ISImpact Measurement Model. Journal of the Association for Information Systems. 9(7), 377-408.

Gewati M. (2019). BI: Industri Pariwisata Jadi Sektor Paling Hasilkan Devisa. Kompas, 2019. https://travel.kompas.com/read/2019/03/23/084500627/bi--industripariwisata-jadi-sektor-paling-hasilkan-devisa.

Hair J. F., Black W. C., Babin B. J., Anderson R. E., and Tatham R.(2006). Multivariate data analysis . Uppersaddle River. NJ: Pearson Prentice Hall, 2006.

Hamrul H., Soedijono B., and Amborowati A. (2013). Mengukur Kesuksesan Penerapan Sistem Informasi Akademik (Studi Kasus Penerapan Sistem Informasi Stmik Dipanegara Makassar). Semin. Nas. Inform. 2013, 140-146.

Iivari J. (2005). An Empirical Test of the DeLone-McLean Model of Information System Success. Data Base Adv. Inf. Syst., 36(2), 8-27.

Kodyat H. (2013). Sejarah kepariwisataan \& perkembangannya di Indonesia. Jakarta: Kementerian Pariwisata dan Ekonomi Kreatif, Republik Indonesia, 2013.

Law R., Leung K., and Wong R. (2004). The impact of the Internet on travel agenciesInt. J. Contemp. Hosp. Manag., 16(2), 100-107

ee K. C. and Chung N. (2009). Understanding factors affecting trust in and satisfaction with mobile banking in Korea: A modified DeLone and McLean's model perspective. Interact. Comput., 21(5-6), 385-392.

Liu C. and Arnett K. P. (2000). Exploring the factors associated with Web site success in the context of electronic commerce. Inf. Manag., 38(1), 23-33. 
Lohmann M. and Schmücker D. J. (2009). Internet research differs from research on internet users: some methodological insights into online travel research. Tour. Rev., 64(1), 32-47.

Mudzana T. and Maharaj M. (2015). Measuring the success of business-intelligence systems in South Africa: An empirical investigation applying the DeLone and McLean Model. SA J. Inf. Manag., 17(1), 1-7.

Omarini A. (2018). The Retail Bank of Tomorrow: A Platform for Interactions and Financial Services. Conceptual and Managerial Challenges. Res. Econ. Manag.

Petter S., Delone W., and Mclean E. R. (2015). The Quest for the Independent Variables Information Systems Success: The Quest for the Independent Variables. Journal of Management Information Information Systems Success, 37-41

Pranoto L. M. E. (2016). Sistem informasi vs Tekenologi Informasi, BINUS University.

Rai A., Lang S. S., and Welker R. B.(2002). Assessing the validity of IS success models: An empirical test and theoretical analysis. Inf. Syst. Res., 13(1), 50-69.

Safdari R., Ghazisaeidi M., Jebraeily M., Masarat E., and Shikhtayefeh M. (2014). A study based on the model adjusted DeLone and McLean in UMSU hospitals Hospital information systems success: A study based on the model adjusted DeLone and McLean in UMSU hospitals Pelagia Research Library. Hospital information systems success.

Scott M., Delone W., and Golden W. (2011), It Quality and Government Net Benefits: A Citizen Persepective.

Seddon P. (1997). A respecification and extension of the DeLone and McLean model of IS. Information Systems Research. Inf. Syst. Res., 8(3), 240-253.

Sekaran R. and Bougie U. (2016), Research Method for Business: A skill building approach - 7th Edition. 2016.

Shapiro D. and Shi X.(2008). Market segmentation: The role of opaque travel agencies. J. Econ. Manag. Strateg., 17(4), 803-837.

Stewart K. J. (2003). Trust transfer on the World Wide Web. Organ. Sci.,14(1), 517. 
Tan Barney L.; Pan, S. L.; Lu, X.; Huang (2015). The Role of IS Capabilities in the Development of Multi-Sided Platforms: The Digital Ecosystem Strategy of Alibaba.com. J. Assoc. Inf. Syst. .

Teo T. S. H., Srivastava S. C., and Jiang L. (2008). Trust and electronic government success: An empirical study. J. Manag. Inf. Syst., 25(3), 99-132

Vilarinho T. A. (2014). Pursuit of competitive advantage for Online Travel Agencies: Driving from price to value. 1-75, 2014.

Wu J. H. and Wang Y. M. (2006). Measuring KMS success: A respecification of the DeLone and McLean's model. Inf. Manag., 43(6), 728-739. 